\title{
Pembaharuan Hukum Islam Di Indonesia Studi Kasus CLD Kompilasi Hukum Islam
}

\author{
Nurjihad
}

\section{Abstract}

The development of Islamic Law (fikih) meets the needs of society which is called upon to resolve increasingly complex issues. This is to the benefit of the Islamic community. However the term "benefit to the community" cannot be understood outside of the context of the protection of the aim of Islamic law which place regulation as the parameters of "benefit". In order to achieve this, ulama (Islamic Scholar) from a number of disciplines proclaim a collective itithad (interpretation, jamai) which is thus able to solve new legal problems as fairly as possible.

\section{Pendahuluan}

Gagasan pembaharuan hukum Islam di Indonesia dewasa ini terus bergulir. Seperti biasanya, terhadap ide atau gagasan yang "baru' tersebut senantiasa menimbulkan kontroversi di berbagai kalangan. Fatwa Majelis Ulama Indonesia (MUI) mengenai haram hukumnya bunga bank di penghujung tahun 2003 yang lalu, menimbulkan pro dan kontra tidak saja dikalangan ulama, namun juga meluas dikalangan pelaku bisnis/usaha. Perbedaan pendapat dan sikap atas fatwa tersebut hingga kini masih berlangsung. Gagasan kontroversial berikutnya terjadi di penghujung tahun 2004 (September) yang dilakukan oleh Tim Pengarusutamaan Gender (PUG) Departemen Agama Rl dengan gagasannya berupa Counter Legal Draft Kompilasi Hukum Islam (KHI).

Terdapat perbedaan tanggapan/respon terhadap dua hal tersebut di atas. Tanggapan terhadap fatwa bunga bank haram relatif seimbang antara yang setuju dengan yang menolaknya, menggunakan alasan/ argumentasi yang jelas, rasional dan tidak emosional. Berbeda halnya tanggapan terhadap counter legal draft $\mathrm{KHI}$, yang cenderung sebaliknya, yakni selain pada umumnya tidak setuju atau menolaknya, juga tidak jarang menggunakan bahasa atau ungkapan yang emosional.

Dalam literatur Hukum Islam Kontemporer, dikenal kata tajdid yang semakna dengan kata "pembaruan". Tajdid mengandung arti membangun kembali, menghidupkan kembali, menyusun kembali atau memperbaikinya agar dapat dipergunakan sebagaimana yang diharapkan. Perkataan tajdid dalam pembaruan hukum Islam mempunyai dua makna, pertama, apabila dilihat dari segi sasaran, dasar, landasan dan sumber yang tidak berubahubah, maka pembaruan bermakna mengembalikan segala sesuatu kepada aslinya. Kedua, pembaruan bermakna 
modernisasi, apabila tajdid itu sasarannya mengenai hal-hal yang tidak mempunyai sandaran, dasar dan sumber yang berubahubah seperti metode, sistem, teknik, strategi dan lainnya untuk disesuaikan dengan situasi dan kondisi, ruang dan waktu.'

Di samping makna sebagaimana tersebut di atas, ada pula yang memaknai pembaruan dengan menekankan kepada penyesuaian pemahaman dikarenakan perkembangan baru yang ditimbulkan sebagai akibat kemajuan ilmu pengetahuan dan teknologi modern. Yusuf Qardhawi berpendapat bahwa pembaruan adalah upaya mengembalikannya pada keadaan semula sehingga ia tampil seakan barang baru. Hal itu dapat dilakukan dengan cara memperkokoh sesuatu yang lemah, memperbaiki yang usang dan menambal yang retak sehingga kembali mendekat pada bentuknya yang pertama. ${ }^{2}$ Dengan demikian pembaruan hukum Islam memang langkah yang harus dilakukan oleh mereka yang mempunyai kompetensi/otoritas dalam pengembangan hukum Islam (mujtahio), dengan cara yang sesuai dengan kaedahkaidah istimbath hukum yang benar.

Upaya pembaharuan hukum Islam di Indonesia tidak hanya masuk pada wilayah wacana, namun lebih kongkrit masuk dan diatur dalam berbagai peraturan perundang-undangan. Peraturan-peraturan dimaksud diantaranya adalah: UU Nomor 1
Tahun 1974 tentang Perkawinan, UU Nomor 7 Tahun 1989 tentang Peradilan Agama, UU Nomor 10 Tahun 1998 tentang Perubahan UU Nomor 7 Tahun 1992 tentang Perbankan, UU Nomor 38 Tahun 1999 tentang Pengelolaan Zakat dan juga pada tahun 2004 ini telah disetujui undang-undang tentang wakaf.

Pada akhir tahun 2003, Badan Pembinaan dan Pengkajian Hukum Islam (BPPHI) Departemen Agama telah menyusun draft Rancangan Undang-Undang tentang Hukum Terapan Peradilan Agama, khususnya dibidang perkawinan. RUU ini dimaksudkan selain sebagai implementasi UU Nomor 25 Tahun 2000 tentang Program Pembangunan Nasional (Propenas), yang menyatakan salah satu indikasi keberhasilan di bidang hukum jika peradilan agama memiliki hukum materiil sendiri, juga merespon keinginan banyak pihak tentang perlunya perubahan pengaturan hukum Kompilasi Hukum Islam dari Instruksi Presiden (Inpres Nomor 1 Tahun 1991) menjadi Undang-undang, agar dapat dijadikan dasar hukum yang "mengikat" bagi hakim Pengadilan Agama, maupun para pihak pencari keadilan.

Upaya untuk "memperbarui" Kompilasi Hukum Islam tersebut makin menarik perhatian publik, ketika beberapa waktu yang lalu Tim Pengarusutamaan Gender (PUG) Departemen Agama Rl melontarkan ide/ gagasannya yang kontroversial berupa

${ }^{1}$ Abdul Manan,"Peranan Peradilan Agama Dalam Perspektif Pembaharuan Hukum Islam: Studi Kasus terhadap Putusan-Putusan Di lingkungan Peradilan Agama DKI Jakarta," Ringkasan Disertasi, Program Pascasarjana USU, Medan, 2004, hlm. 45-46. Lihat pula Fathurrahman Djamil, Metode litihad Majelis Tarjih Muhammadiyah (Jakarta: Logos Publishing House, 1995), hlm. 6.

2 Yusuf Qardhawi, "Min Ajli Shahwatin Raasyidah Tujaddidud-diin," (Terjemahan) Nabhani Idris, Fiqih Tajdid dan Shahwah Islamiah (Jakarta: Islamuna Pres, 1997), him. 28. 
Counter Legal Draft Kompilasi Hukum Islam (KHI). Menurut tim, KHI perlu dibaca ulang terutama dalam perspektif gender, pluralisme, dan demokrasi. KHI dianggap selain bias gender, juga belum memenuhi tuntutan keadilan masyarakat Indonesia

\section{Latar Belakang Lahirnya KHI}

Istilah "kompilasi" dalam khazanah kepustakaan ilmu hukum di Indonesia secara relatif masih belum banyak dibahas, terutama bila dibandingkan dengan istilah "kodifikasi" yang telah dikenal luas dikalangan masyarakat. Dalam kamus hukum berbahasa Indonesia juga belum terdapat uraian tentang makna kompilasi. Begitu pula KHI yang ditetapkan dalam tahụn 1991 tidak pemah menyebut secara tegas makna kompilasi maupun $\mathrm{KHI} .^{3}$

Dalam bahasa latin ditemukan kata compilatio dengan arti "kumpulan (terdiri dari kutipan-kutipan, buku-buku lain)". ${ }^{4}$ Dalam bahasa Inggris, kamus susunan Echols dan Shadily menulis arti compilation sebagai "himpunan, kompilasi dan istilah compilation of laws diberi arti sebagai "himpunan undangundang". ${ }^{5}$ Kamus besar bahasa Indonesia, menjelaskan kata "kompilasi" dengan sebutan "kumpulan yang tersusun secara teratur (tentang daftar informasi, karangan-karangan, dan

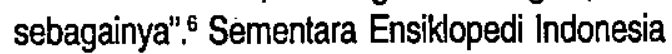

menerangkan, yang dimaksud kompilasi adalah "suatu buku yang merupakan himpunan karangan berbagai penulis"?

Keterangan tersebut di atas sekalipun memberi makna secara harfiah, tetapi dapat memberi petunjuk bahwa kompilasi merupakan suatu perbuatan atau tindakan penghimpunan berbagai bahan, karangan maupun informasi untuk disusun ke dalam suatu buku secara teratur. Pengertian ini masih menyentuh kegiatan berbagai bidang secara umum dan belum memberi sisi sebagai produk hukum sebagaimana di kandung dalam istilah kodifikasi. ${ }^{8}$ Apabila kompilasi dihubungkan dengan hukum Islam yang kemudian disebut dengan Kompilasi Hukum Islam, maka dapat dirumuskan sebagai himpunan kaidah-kaidah hukum Islam yang disusun secara sistematis selengkap mungkin dengan berpedoman pada rumusan kalimat atau pasal-pasal yang lazim digunakan dalam peraturan perundangan. ${ }^{9}$

Dilihat dari proses pembentukannya, $\mathrm{KHI}$ merupakan himpunan kaidah-kaidah hukum Islam yang berasal dari kitab-kitab fikih, aturanaturan hukum, yurisprudensi dan pendapat ulama (doktrin) ke dalam satu buku hukum yang disusun dalam bentuk dan memakai bahasa perundang-undangan.

Kompilasi Hukum Islam sebagaimana tersebut pada Inpres Nomor 1 Tahun 1991

${ }^{3}$ Muhammad Arifin, "Perkembangan Hukum Isiam di Indonesia Kajian Atas Keberadaan Peradilan Agama dan Kompilasi.Hukum Islam", Tesis, PPS-USU, Medan, hlm. 161.

${ }^{4}$ K.Prent C.M., dkk., Kamus Latin Indonesia (Yogyakarta: Kanisius, 1969), hlm. 160.

${ }^{5}$ John M.Echols dan hasan Shadily, Kamus Inggris-Indonesia (Jakarta: Gramedia, 1975), hlm. 132.

${ }^{6}$ Departemen Pendidikan dan Kebudayaan, Kamus Besar Bahasa Indonesia (Jakarta: Balai Pustaka, 1989), him. 453.

7 Muhammad Arifin, op.cit., hlm. 162.

${ }^{8}$ lbid., hlm. 163

${ }^{9}$ H.M.Tahir Azhary, "Kompilasi Hukum Islam Sebagai Alternatif: SuatuAnalisis Sumber-Sumber 
lahir diłatarbelakangi oleh tidak adanya satu kitab hukum resmi sebagai rujukan standar yang dipergunakan menjadi dasar dalam memberi putusan di lingkungan badan peradilan agama, seperti halnya yang ada di lingkungan peradilan umum (KUHPerdata). Sebelumnya para hakim agama mempergunakan berbagai kitab fikih susunan para fagih beberapa abad silam sebagai dasar pengambilan putusan. Akibatnya terjadi ketidakseragaman dalam menentukan dasar bagi produk putusan pengadilan agama. $\mathrm{Hal}$ itu terjadi karena para hakim dalam memberikan putusannya dipengaruhi oleh latar belakang rujukan yang dipedomaninya. Lebih kronis lagi bila hakim terlalu fanatik pada rujukan tertentu dan tidak mau beranjak dari rujukan tersebut, akibatnya lahirlah putusanputusan peradilan agama yang saling berbeda dasar hukumnya antara putusan yang satu dengan lainnya, meskipun kasus perkaranya sama. Apabila kebetulan hakim yang memberi putusan pada tingkat pertama berbeda kitab rujukannya dengan hakim yang lain pada tingkat banding, maka tidak dapat dihindarkan lagi terjadi putusan yang berbeda. ${ }^{10}$ Produk peradilan agama yang saling berbeda tersebut tidak sejalan dengan prinsip kepastian hukum yang diperlukan dalam suatu penegakan hukum.

Menyadari perlunya ada kitab hukum yang menjadi acuan untuk memutus perkara bagi para hakim agama, sesungguhnya telah direspon oleh Departemen Agama dengan mengeluarkan SE No.B/1/735, tanggal 18 Februari 1958 yang menentukan 13 (tigabelas) kitab fikih sebagai pedoman hakim dalam memeriksa dan memutus perkara di lingkungan peradilan agama." Penunjukan ketigabelas kitab fikih itu tidaklah secara tuntas mengurangi ketidakpastian dilingkungan peradilan agama. Tidak jarang pula terjadi perselisihan sesama hakim sendiri dalam menentukan pemilihan kitab rujukan. ${ }^{12}$ Ide penyusunan KHI baru diwujudkan pada Tahun 1985, dengan penandatanganan Surat Keputusan Bersama (SKB) Ketua Mahkamah Agung dan Menteri Agama No.07/KMA1985 tentang Penunjukan Pelaksana Proyek Pembangunan Hukum Islam Melalui Yurisprudensi. Tugas utama tim tersebut adalah melaksanakan pembangunan hukum Islam melalui yurisprudensi dengan jalan kompilasi hukum. Sasarannya mengkaji kitabkitab yang dipakai sebagai dasar putusanputusan hakim agar sesuai dengan perkembangan masyarakat Indonesia untuk menuju hukum nasional. Pada tanggal 29 Desember 1987, secara resmi naskah rancangan $\mathrm{KHI}$ selesai. Selanjutnya setelah dilokakaryakan pada tanggal 2-6 Februari di Jakarta dengan diikuti 126 peserta. (ulama dan

Hukum Islam," dalam Tim Ditbinbapera, BerbagaiPandangan Terhadap Kompilasi Hukum Islam (Jakarta: Yayasan Al-Hikmah, 1993/1994), him. 135.

${ }^{10}$ Muhammad Arifin, op.cit., hlm.147. Lihat pula pada Busthanul Arifin, "Kompilasi: Fikih Dalam Bahaa Undang-undang," Pesantren, No.2Nol.II/1985, hlm. 27.

- "Ketigabelas kitab dimaksud adalah: (1)Albajuri; (2) Fathul Mu'in; (3) Syarqowi 'alat Tahrir; (4) Qalyubi/ Mahalli; (5) Fathul Wahhab dengan syarahnya; (6) Tuhfah; (7) Targhibul Musyataq; (8) Qawanin Syar'iyah lis Sayyid bin Yahya; (9) Qawanin Syar'iyah lis Sayyid bin Saqadah Dahlan; (10) Syamsuri fil Faraidl; (11) Bughyatul Musytarsyidin; (12) Alfikihu’ala Madzahibil Arba'ah; dan (13) Mughnil Muhtaj.

${ }^{12}$ Busthanul Arifin, loc.cit 
cendekiawan muslim) disepakatilah (ijma) sebagai naskah akhir KHI. Selanjutnya naskah akhir tersebut disampaikan kepada Presiden oleh Menteri Agama dengan surat tanggal 14 Maret 1988 dengan maksud untuk memperoleh bentuk yuridis untuk digunakan dalam praktek di lingkungan peradilan agama.

Setelah hukum materiil yang berbentuk kompilasi diselesaikan, maka berikutnya dibutuhkan wadahnya, dan untuk sementara kompilasi tersebut disimpan. Dengan lahirnya Undang-undang Nomor 7 Tahun 1989, maka wadah dimaksud telah terbentuk dan kompilasi yang berisi hukum materiil dapat lebih dimatangkan. Keadaan ini, lahirnya UU Nomor 7 Tahun 1989, pulalah yang menjadi pendorong kuat untuk memacu lahirnya Kompilasi Hukum Islam sebagai hukum materiil di lingkungan peradilan agama. ${ }^{13}$

Dalam praktik, khususnya dilingkungan peradilan agama, saat ini meskipun bukan merupakan undang-undang yang mempunyai kekuatan mengikat, $\mathrm{KHI}$ telah mendapatkan pengakuan yang baik di kalangan hakim peradilan agama, terbukti hampir seluruh putusan-putusan pengadilan dalam lingkungan peradilan agama. selalu mendasarkan ketentuan/pasal-pasal dalam $\mathrm{KHI}$. Hal itu sesungguhnya dapat dipandang sebagai indikator penerimaan/persetujuan atas isi $\mathrm{KHL}$ di kalangan pengadilan dalam lingkungan peradilan agama. Bahkan dikalangan masyarakat luas-pun, $\mathrm{KHI}$ telah menjadi acuan/pedoman dalam menyelesaikan masalah-masalah di bidang perkawinan, kewarisan dan perwakafan.

\section{Materi Counter Legal Draft}

Menurut tim PUG, KHI dipandang tidak lagi memadai dalam menyelesaikan pelbagai problem keumatan yang cukup kompleks. Konstruksi KHI sejak awal kelahirannya telah membawa kelemahan-kelemahan pokok, khususnya bila didekati dari perspektif gender, pluralisme, hak asasi manusia dan demokrasi. Lebih jauh tim menyatakan bahwa $\mathrm{KHI}$ dalam sejarahnya adalah produk kebijakan hukum pemerintah yang proses penyusunannya didasarkan pada hukum normatif Islam, terutama fikih madzhab Syafi'l, sehingga KHI tampil dalam wajah yang tidak akrab dengan hukum-hukum nasional dan internasional yang memiliki komitmen kuat pada tegaknya masyarakat yang egaliter, pluralis dan demokratis.

Tim PUG menjelaskan pula, bahwa pembaruan yang dilakukan bukan hanya pada basis materialnya yang terhampar dalam pasal demi pasal $\mathrm{KH}$, melainkan juga pada pangkal paradigmanya. Perubahan-perubahan yang memicu kontroversi dimaksud adalah sebagai berikut: ${ }^{14}$

${ }^{13}$ Abdurrahman, Kompilasi Hukum Islam Dilndonesia (Jakarta: Akademika Pressindo, 1992), hlm.49. Lihat pula Munawir Sjadzali, "Peradilan Agama Dan Kompilasi Hukum Islam”, dalam Moh.Mahfud MD, dkk., (Eds), Peradilan Agama Dan Kompilasi Hukum Islam Dalam Tata Hukum Indonesia (Yogyakarta: UII Press, 1993), hlm. 3-4.

${ }^{14}$ Forum Keadilan, Nomor 26, Tanggal 24 Oktober 2004, hlm. 20. 


\section{Hukum Perkawinan}

\begin{tabular}{|c|c|c|}
\hline Isu Krusial & KHI 1991 & CLD KHI \\
\hline Pernikahan & Pelaksanaannya merupakan ibadah (Pasal 2) & $\begin{array}{l}\text { Bukan Ibadah, hanya kontrak yang didasarkan pada } \\
\text { kesepakatan kedua pihak (Pasal 2) }\end{array}$ \\
\hline Wali nikah & Merupakan rukun perkawinan (Pasal 14) & Bukan rukun perkawinan (Pasal 6) \\
\hline Pencatatan & Tidak termasuk rukun perkawinan (Pasal 14) & Merupakan rukun perkawinan (Pasal 6) \\
\hline $\begin{array}{l}\text { Ke s a k s i a } n \\
\text { perempuan dalam } \\
\text { perkawinan }\end{array}$ & $\begin{array}{l}\text { Perempuan tidak boleh menjadi saksi (Pasal } \\
\text { 25) }\end{array}$ & Perempuan boleh menjadi saksi (Pasal 11) \\
\hline $\begin{array}{l}\text { Batas minimal usia } \\
\text { perkawinan }\end{array}$ & $\begin{array}{l}16 \text { th bagi calon isteri, } 19 \text { th bagi calon suami } \\
\text { (Pasal 15) }\end{array}$ & $\begin{array}{l}19 \text { th, dengan tidak membedakan calon isteri dan } \\
\text { suami (Pasal } 7 \text { ). }\end{array}$ \\
\hline Mahar & Diberikan calon suami kepada calon isteri & $\begin{array}{l}\text { Mahar dimungkinkan diberikan oleh calon isteri } \\
\text { kepada calon suami (Pasal 16) }\end{array}$ \\
\hline $\begin{array}{l}\text { Kedudukan suami- } \\
\text { isteri }\end{array}$ & $\begin{array}{l}\text { Suami adalah kepala keluarga dan istri ibu } \\
\text { rumah tangga (Pasal } 79 \text { ) }\end{array}$ & $\begin{array}{l}\text { Kedudukan, hak, dan kewajiban suami-isteri adalah } \\
\text { setara (Pasal } 49 \text { ) }\end{array}$ \\
\hline $\begin{array}{l}\text { Perjan jia n } \\
\text { perka wina n } \\
\text { berjangka }\end{array}$ & Tidak diatur & $\begin{array}{l}\text { Diatur, sehingga perkawinan dinyatakan bubar } \\
\text { bersamaan dengan berakhirnya masa perkawinan } \\
\text { (Pasal } 22 \text { dan } 28 \text { ) }\end{array}$ \\
\hline $\begin{array}{l}\text { Pencarian nafkah } \\
\text { Kawin beda agama }\end{array}$ & $\begin{array}{l}\text { Kewajiban suami (Pasal } 80 \text { ) } \\
\text { Mutlak tidak boleh (Pasal } 44 \text { dan } 61 \text { ) }\end{array}$ & $\begin{array}{l}\text { Kewajiban bersama bagi isteri dan suami (Pasal 51) } \\
\text { Boleh, selama dalam batas untuk mencapai tujuan } \\
\text { perkawinan (Pasal } 54 \text { ) }\end{array}$ \\
\hline $\begin{array}{l}\text { Poligami } \\
\text { Iddah }\end{array}$ & $\begin{array}{l}\text { Boleh, dengan catatan (Pasal 55-59) } \\
\text { lddah hanya untuk isteri (Pasal 153) }\end{array}$ & $\begin{array}{l}\text { Mutlak tidak boleh (Pasal 3) } \\
\text { Iddah berlaku bagi isteri dan suami (Pasal 88) }\end{array}$ \\
\hline Nusyuz & $\begin{array}{l}\text { Nusyuz hanya dimungkinkan oleh istri (Pasal } \\
\text { 84) }\end{array}$ & Nusyuz juga bisa dilakukan suami (Pasal 53) \\
\hline $\begin{array}{l}\text { Khulu' (perceraian } \\
\text { atas inisiatif istri) }\end{array}$ & $\begin{array}{l}\text { Khulu' dinyatakan sebagai talak bain sughra, } \\
\text { shg tidak boleh rujuk melainkan harus nikah } \\
\text { baru (Pasal } 119 \text { ) }\end{array}$ & $\begin{array}{l}\text { Khufu' dan talak adalah sama sehingga pelakunya } \\
\text { boleh rujuk (Pasal } 1 \text { dan } 59 \text { ) }\end{array}$ \\
\hline $\begin{array}{l}\text { Hak rujuk (bersatu } \\
\text { kembali) }\end{array}$ & $\begin{array}{l}\text { Hak rujuk dimiliki suami, bukan isteri Pasal } \\
\text { 163) }\end{array}$ & $\begin{array}{l}\text { Suami maupun istri memiliki hak untuk rujuk (Pasal } \\
\text { 105) }\end{array}$ \\
\hline
\end{tabular}

\section{Hukum Kewarisan}

\begin{tabular}{|l|l|l|}
\hline \multicolumn{1}{|c|}{ IsU krusial } & \multicolumn{1}{|c|}{ KHI 1991 } & \multicolumn{1}{c|}{ CLD KHI } \\
\hline Waris Beda Agama & $\begin{array}{l}\text { Beda agama menjadi penghalang proses } \\
\text { waris-mewaris (Pasal 171-172) } \\
\text { Hanya memiliki waris dari pihak ibunya, } \\
\text { sekalipun ayah biologisnya sudah } \\
\text { Anak luar kawin }\end{array}$ & $\begin{array}{l}\text { Beda agama bukan penghalang proses waris } \\
\text { mewarisi } \\
\text { Jika ayah biologisnya diketahui, si anak tetap memiliki } \\
\text { hak waris dari ayah biologisnya (Pasal 16) }\end{array}$ \\
$\begin{array}{l}\text { Dipakai (Pasal 192-193) } \\
\text { Bagian anak laki-laki dan perempuan } \\
\text { Pembagian waris } \\
\text { adalah 2:1 }\end{array}$ & $\begin{array}{l}\text { Dihapus } \\
\text { Proporsinya sama, 1:1 atau 2:2 }\end{array}$ \\
\hline
\end{tabular}

\section{Hukum Wakaf}

\begin{tabular}{|c|l|l|}
\hline Isu krusial & \multicolumn{1}{|c|}{ KHI 1991 } & \multicolumn{1}{c|}{ CLD KHI } \\
\hline HAKI sebagai barang wakaf & Tidak diatur & Diatur (Pasal 11) \\
\hline
\end{tabular}


Perubahan radikal sebagaimana terurai di atas, telah mendapatkan tanggapan yang sangat keras dari berbagai kalangan yang pada umumnya beranggapan sebagian besar draft tersebut jelas-jelas bertentangan dengan syari'at Islam. Kecaman banyak pihak yang ditujukan kepada Departemen Agama (Depag) yang menaungi tim pengarusutamaan, membuat Menteri Agama Said Agil Husin al Munawar menegur secara keras tim tersebut dan meminta semua draft asli diserahkan kepada Depag, serta melarang untuk dilakukannya diskusi, sarasehan yang berkaitan dengan draft KHI tersebut. Menteri Agama juga menyatakan bahwa draft tersebut disusun tidak berdasarkan persetujuan Depag, tapi hañya mengatasnamakan Depag. ${ }^{15}$

\section{Counter Legal Draft dan Pembaharuan Hukum Islam}

Meskipun Counter Legal Draft (CLD) KHI telah ditarik oleh Departemen Agama, namun draft tersebut telah beredar dan menjadi milik masyarakat. Terlepas sikap apa yang akan dilakukan oleh Departemen Agama selanjutnya, pikiran-pikiran CLD KHI tersebut patut direspon oleh kalangan ulama, akademisi dan pemerhati hukum Islam untuk menjelajahi lebih dalam "benar-salah"nya konsep tersebut dari perspektif yang lebih komprehensif.

Mencermati uraian bab II CLD KHI dengan topik Menuju KHI Indonesia yang Pluralis dan Demokratis, kesan apriori terhadap KHI 1991 terlihat sangat kuat dan dominan, keduanya (KHI 1991 dan CLD KHI) diposisikan saling berhadap-hadapan. KHI 1991 dianggap sebagai produk yang cacat semenjak lahimya, baik dari prosedur maupun metodologi yang digunakannya. "Ketidakcermatan/kekeliruan" CLD KHI dalam menunjukkan fakta sesungguhnya sangat banyak ditemukan, misal anggapan KHI tidak merespon kenyataan empirik dan "mengangkut" begitu saja penjelasan normatif tafsir keagamaan klasik, mengutip nyaris sempurna seluruh pandangan fikih "purba". ${ }^{16}$ Padahal dalam KHI 1991, cukup banyak ketentuan-ketentuan yang didasarkan atas "kearifan lokal", ${ }^{17}$ misalnya: konsep anak yang sah, wasiat wajibah, pencatatan perkawinan, ijin

${ }^{15}$ Penolakan Departemen Agama atas draft tersebut hanya sehari setelah menerima surat dari Majelis Ulama Indonesia (MUI) yang mempertanyakan draft tersebut. MUI menilai tim tersebut bukan hanya menafsirkan al-Qur'an, tapi menyalahartikannya. Lebih jauh Ketua MUI Umar Shihab menegaskan tidak semua orang bisa menafsirkan al-Qur'an dan Hadist sebagai sumber hukum Islam. Menafsirkan takcukup dengan menggunakan akällogika, tapi diperlukan keahlian bahasa, asbabun nuzul dan sejarah. Prof.Dr.Tahir Azhary, Guru Besar Hukum IslamUl, terang-terangan menganggap beberapa point draft tersebut mengada-ada, lihat SKHRepublika, 5 Oktober 2004. Penolakan keras lainnya dapat dilihat dalam Cholis Akbar, "Kerancuan Metodologi Draft Kompilasi Hukum Islam" http:/www.hidayatullah.com23 Oktober 2004.

${ }^{16}$ Bahasa atau istilah yang digunakan untuk menunjukkan ketidaksetujuannya dengan $\mathrm{KHI}$ atau fikih klasik, punya kesan "kebencian" yang mendalam, seperti penggunaan kata-kata: fikih purba, sakralisasi fikih klasik, terjadinya tindakan eisegese, yakni membawa masuk pikiran atau ideologinya sendiri kedalam nash lalu menariknya keluar dan mengklaimnya sêbagai maksud Tuhan, dsb. Lihat, Tim Pengarusutamaan Gender Depag Rl, Pembaruan Hukum Islam: Counter Legal Draft Kompilasi Hukum Islam, 2004, him. 21-22.

${ }_{17}$ Tim CLD KHI menyebut kebiasaan masyarakat (adat, al-'urf) dengan sebutan kearifan lokal atau kenyataan empirik, dan hal tersebut merupakan salah satu isu utama yang digulirkan dan menjadi dasar pjjak. 
poligami, dispensasi perkawinan, istbat nikah dan sebagainya.

Menjadikan "kearifan lokal" sebagai hukum/sumber hukum Islam sesungguhnya bukan merupakan barang baru, selain -memang dikenal dalam kaidah ushul fikih (aladatu muhakkamah) juga kaitan antara adat dan hukum Islam di Indonesia memang mempunyai catatan sejarah panjang. Dimulai dengan munculnya teori receptio in complexu yang dikemukakan Van Den Berg yang pada pokoknya menyatakan (realitas) hukum yang berlaku di masyarakat Indonesia pada masa pemerintahan Hindia Belanda adalah hukum Islam. Perkembangan berikutnya teori itu dibantah oleh Christian Snouck Hurgronje dengan teorinya receptie yang pada pokoknya menyatakan bahwa hukum yang berlaku di Indonesia adalah hukum adat, hukum Islam baru berlaku kalau diterima oleh hukum Adat. ${ }^{18}$ Selanjutnya muncullah teori receptie a contrario yang dikemukakan oleh Sayuti Thalib yang berpandangan bahwa dimasyarakat Indonesia ketentuan yang berlaku adalah hukum Islam, adapun hukum Adat boleh berlaku kalau tidak bertentangan dengan hukum Islam. ${ }^{19}$

Pandangan tim CLD KHI meskipun tidak sama persis, namun ada kemiripan dengan teori receptie yang dikemukakan $\mathrm{C}$. Snouck Hurgronje. Keduanya menempatkan kenyataan empirik/kearifan lokal (local wis- dom, al-'urf) sebagai dasar pijak/variabel independen yang menjadi faktor dominan dalam pembentukan/penerapan hukum Islam. Tim juga menempatkan akal (publik) pada posisi yang mutlak, adapun nash (teks harfiah) pada posisi yang relatif, sehingga ketika terjadi pertentangan antara akal publik dengan bunyi harfiah teks ajaran, maka akal publik berotoritas untuk mengedit, menyempurnakan, dan memodifikasikannya. ${ }^{20}$ Bahkan dengan tegasnya menyatakan perlu ada perubahan paradigma dari teosentrisme ke antroposentrisme, dan perlu mem-fikihkan syariat atau merelatifkan syariat.21 Pola pikir yang demikian itu bukanlah pola pikir yang berkembang dalam tradisi Islam. Epistemologi atau metodologi penafsiran al-Qur'an dan asSunnah yang digunakan bukanlah metodologi yang digunakan kaum muslim selama ini.

Metodologi yang. dikemukakan tim CLD di atas, cenderung mengarah kepada metode tafsir hermeneutic (hermanitik), yaitu suatu metode untuk memahami dan menafsirkan teks-teks kuno. Metode hermanitik ini sudah berkembang sejak masa kejayaan Yunani kuno. Pada masa itu metode hermanitik dipergunakan oleh Aristoteles sebagaimana terdapat dalam bukunya Peri Hermenias atau De Interpretation. Menurut Aristoteles, kata yang diucapkan merupakan simbol dari pengalaman mental. Kata-kata yang ditulis adalah simbol dari kata-kata yang diucapkan,

Tim juga mengklaim bahwa perubahan-perubahan sebagaimana terdapat dalam pasal-pasal CLD KHI sebagai "keinginan atau kebiasaan" yang terjadi di masyarakat Indonesia.

${ }^{18}$ Abdul Manan, Hukum Islam Dalam Berbagai Wacana (Jakarta: Pustaka Bangsa, 2003), hlm.6.

$19 \mathrm{lbid}$, hlm. 14.

20 Tim Pengarusutamaan Gender Depag RI, op.cit., hlm.24.

21 Ibid., him. 23. 
oleh karenanya diperlukan penafsiran yang akurat dan benar untuk mencapai hakikat kebenaran yang hakiki.22 Pemikiran demikian itu dihidupkan kembali oleh pemuka-pemuka agama Protestan untuk menafsirkan Bible (Perjanjian Lama dan Perjanjian Baru) atas teksteks asli yang telah mati. Sebagaimana diketahui, Bible telah mengalami multitransliterasi dari bahasa aslinya, yang oleh karenanya sangat mungkin terjadi perubahan makna. ${ }^{23}$

Banyak pemikir Islam modem, yang tertarik pula untuk menggunakan metode hermanitik ini sebagai metode untuk melakukan pembaruan hukum Islam, diantaranya adalah Fazlur Rahman. Namun demikian metode hermanitik ini dalam khazanah pemikiran islam belum mendapatkan dukungan yang cukup dikalangan para pemikir/intelektual muslim, khususnya apabila digunakan sebagai metode tafsir alQuran. Ada perbedaan fundamental antara teksteks sejarah kuno, kitab-kitab suci agama lain (Bible) dengan al-Quran. Al-Qur'an merupakan kitab suci yang diturunkan oleh Allah kepada $\mathrm{Nabi}$ Muhammad SAW secara lengkap dan sistematis, baik teks maupun maknanya.

Fazlur Rahman pun dalam upaya pembaruan hukum Islam, tetap berpandangan bahwa metode yang perlu dipergunakan bukan hanya metode hermanitik, melainkan tetap juga menggunakan metode ushul fikih dan critical histori. Untuk penerapan metode hermenitik, menurutnya masih dibutuhkan bantuan metode sosio histories. ${ }^{24}$

Penerapan metode hermanitik hingga sekarang ini sesungguhnya juga belum menunjukkannya sebagai metodologi dan karya yang utuh dan menyeluruh. Pada umumnya metode ini baru/hanya mendekonstruksi sejumlah aspek saja yang "dianggap" tidak sesuai dengan konteks kondisi sekarang. ${ }^{25}$ Atas hal tersebut, sudah sepatutnya penggunaan metode hermanitik ini terlebih dahulu dibicarakan dikalangan ulama (ijma) untuk disepakati dapat tidaknya dipergunakan sebagai alternatif metode penafsiran al-Qur'an. Terhadap hal-hal yang masih berselisih pandangan secara tajam, maka untuk kemaslahatan ummat, perlu dikaji lebih mendalam . dan dihindarkan dalam penggunaannya sebagai sebuah metode untuk sementara, agar terhindar dari keragu-raguan.

Dari perspektif gender, tim CLD KHI membuat klaim, bahwa tradisi fikih Islam didominasi laki-laki. Hukum Islam yang dipahami, diyakini dan diamalkan sehari-hari dilahirkan oleh masyarakat dan budaya patriarkhis dimana laki-laki selalu menjadi pusat kuasa dan misoginis ${ }^{26}$ sering dianggap

'22 Ghuiron A.Masadi, Pemikiran Fazlur Rahman Tentang Metodologi Pembaharuan Hukum Islam (Jakarta: Raja Grafindo, 1998), hIm. 70-71.

${ }^{23}$ Siddiq Al-Jawi, "Hermeneutik Al-Qur'an Tidak Perlu", UIINews, Edisi 18, Th.II, 17 Oktober 2004, him.7.

${ }^{24}$ Abdul Manan, op.cit., him. 144.

${ }^{25}$ Cholis Akbar, op.cit,, hlm. 1

${ }^{26}$ Misoginis (kebencian terhadap perempuan), kesimpulan ini sama sekali tidak didukung oleh fakta atau hasil penelitian yang representatif dan lebih bersifat pendapat (opini) Tim CLD KHI. Perbedaan pendapat adalah hal yang wajar, bahkan merupakan keniscayaan, selama hal itu dilandasi oleh itikad baik, argumentatif dan konstruktif serta bukan "kebencian". Lihat pula catan kaki nomor 14.

${ }^{27}$ lbid., hlm.30. 
wajar dalam penafsiran. ${ }^{27}$ Dengan ungkapan lain, tafsir yang ada selama ini adalah bias gender. Fenomena dan pandangan yang demikian itu sesungguhnya terjadi pula dikalangan kaum kristiani. Kaum feminis kristen, sejak lama berusaha keras bagaimana agar gerakan mereka mendapatkan legitimasi dari Bible. Mereka tidak lagi menulis God, tetapi juga Goddes. Sebab gambaran Tuhan dalam agama mereka adalah Tuhan maskulin. Mereka ingin adanya Tuhan yang (bersifat) perempuan. Tuhan yang bukan huwa tetapi hiya. Dalam buku Feminist Aproaches to The Bible (Washington: Biblical Archeology Society, 1995) seorang aktivis perempuan, Tivka Frymer-Kensky, menulis makalah dengan judul: Goddesses: Biblical Echoes. Tahun 1895, Elizabeth Cady Stanton menerbitkan buku "The Women's Bible", dimana ia mengkaji seluruh teks Bible yang berkaitan dengan perempuan. Kesimpulannya, Bible mengandung ajaran yang menghinakan perempuan. Lebih jauh menurut Stanton, Bible . bukanlah kata-kata Tuhan, tetapi sekedar koleksi tentang sejarah dan mitologi yang ditulis oleh kaum laki-laki. Sebab itu, perempuan tidak memiliki kewajiban moral untuk mengikuti ajaran Bible. Kaum feminis Kristen tidak berani membuang Bible, tetapi melakukan perombakan terhadap metode interpretasinya. ${ }^{28}$

Problema dalam tradisi kristen di atas, tampak jelas ada kemiripan dengan apa yang dilakukan oleh Tim CLD KHI. Dengan menjadikan gender equality dalam konsep barat sebagai basis berpikir, selanjutnya menganalisis al-Qur'an dan secara implisit menyatakannya al-Qur'an bias gender, kecuali jika ditafsir ulang. Problema praktis dan partikular yang dihadapi kaum wanita memang banyak diantara mereka yang tertindas - ditarik ke akar ideologis dan epistemologis. Seolah-olah, semua itu adalah karena kesalahan ulama Islam masa lalu, yang merumuskan fikih yang berpihak pada laki-laki.. ${ }^{29}$ Tim CLD KHI bahkan menyatakan merekonstruksi hukum Islam (fikih) dewasa ini tidak cukup sekedar melakukan tafsir ulang, tetapi harus melalui proses dekonstruksi (pembongkaran) terhadap bebatuan ideologi yang melilitnya berabad-abad. ${ }^{30}$

Langkah pembaruan yang dilakukan oleh Tim CLD KHI sesungguhnya merupakan langkah yang pafiut diapresiasi dalam upayanya menyesuaikan dengan tuntutan dinamika masyarakat dan perkembangan zaman. Namun demikian, pembaruan tersebut haruslah benar-benar dilatarbelakangi oieh kondisi/fakta yang memang menuntut adanya perubahan, dan bukannya sekedar opini atau hal-hal bersifat kasuistik belaka yang secara metodologi tidak cukup untuk digeneralisir.

Selanjutnya mengembangkan pemikiran keislaman, tidak dapat diabaikan pemikiranpemikiran keislaman terdahulu. Karena historis-lah yang memberikan kontiniutas kepada wujud intelektual dan spiritual masyarakat. Tidak ada satu masyarakatpun yang bisa menghapus masalahnya yang telah terjadi dan mengharapkan untuk menciptakan wujud masa depan bagi dirinya yang lebih baik dari waktu sebelumnya. Untuk upaya

\footnotetext{
${ }^{28}$ Cholis Akbar, op.cit., hlm.2.

${ }^{29} \mathrm{lbid}$.

${ }^{30}$ Tim Pengarusutamaan Gender Depag Rl, op.cit., hlm.30.
} 
pembaruan hukum Islam haruslah dilakukan kajian yang komprehensif, termasuk di dalamnya kajian historis-sistematis mengenai perkembangan hukum Islam.

Pembaruan tersebut juga harus benarbenar bertujuan untuk kemaslahatan ummat. Yusuf Amir dalam kitabnya al Maqashid memberikan parameter maslahah dalam pengertian hukum: ${ }^{31}$ pertama, yang menjadi sandaran dan maslahah itu selalu petunjuk syara' bukan semata-mata berdasar akal manusia, karena akal manusia itu tidak sempurna, bersifat relatif dan subyektif, selalu dibatasi oleh waktu dan tempat serta selalu terpengaruh oleh lingkungan dan dorongan hawa nafsu; kedua, pengertian maslahat atas sesuatu yang baik dan buruk dalam pandangan syara' tidak terbatas untuk kepentingan dunia saja tetapi juga untuk kepentingan akhirat, tidak untuk kepentingan semusim, tetapi berlaku untuk sepanjang masa; ketiga, maslahah dalam arti syara'tidak terbatas pada rasa enak dan tidak enak dalam artian fisik jasmani saja, tetapi juga enak dan tidak enak dalam artian mental spiritual atau secara rohaniah.

\section{Simpulan}

- Untuk kepentingan kemaslahatan ummat, pembaruan hukum Islam (fikih) merupakan kebutuhan dan keniscayaan sesuai dengan karakter fikih yang dalam hal tertentu bersifat kondisional. Namun demikian, pengertian dan ukuran kemaslahatan ummat haruslah tidak keluar dari konteks memelihara tujuan hukum Islam, dengan menolak bencana atau kerusakan atau sesuatu yang meragukan. Parameter maslahah adalah syara'. Sesuatu dikatakan maslahah apabila sejalan dengan tindakan syara' dan tujuan syara'. Adapun tujuan syara' adalah memelihara agama, jiwa, akal, harta benda dan keturunan atau kehormatan. Selanjutnya untuk menyelesaikan persoalan-persoalan yang makin kompleks, seiring dengan perkembangan ilmu, budaya dan teknologi, perlu mengedepankan ijtihad kolektif (jama'). Dengan melibatkan para ulama/ pakar dari berbagai disiplin ilmu, diyakini akan mampu memecahkan persoalan hukum baru dengan seadil-adilnya.

\section{Daftar Pustaka}

Abdurrahman, Kompilasi Hukum Islam Di Indonesia, Akademika Pressindo, Jakarta, 1992.

Al-Jawi, Siddiq, "Hermeneutik Al-Qur'an Tidak Perlu", UII News, Edisi 18, Th.II, 17 Oktober 2004

Akbar, Cholis, "Kerancuan Metodologi Draft Kompilasi Hukum Islam" http:/ www.hidayatullah.com. Tanggal 23 Oktober 2004.

A.Masadi, Ghufron, Pemikiran Fazlur Rahman Tentang Metodologi Pembaharuan Hukum Islam, Raja Grafindo, Jakarta, 1998.

Arifin, Busthanul, "Kompilasi: Fiqh Dalam Bahasa Undang-undang", Pesantren, No.2Nol..I/1985

Arifin, Muhammad, "Perkembangan Hukum Islam di Indonesia Kajian Atas Keberadaan Peradilan Agama

${ }^{31}$ Amir Syarifuddin, Pembaharuan Pemikiran Dalam Hukum Islam (Padang: Angkasa Raya, 1993), him. 326. 
dan Kompilasi Hukum Islam", Tesis, PPS-USU, Medan, 1996.

Azhary, M.Tahir, "Kompilasi Hukum Islam Sebagai Alternatif: Suatu Analisis Sumber-Sumber Hukum Islam", dalam Tim Ditbinbapera, Berbagai Pandangan Terhadap Kompilasi Hukum Islam, Yayasan Al-Hikmah, Jakarta, 1993/1994.

C.M, K.Prent., dkk., Kamus Latin Indonesia, Kanisius, Yogyakarta, 1969.

Djamil, Fathurrahman, Metode ljtihad Majelis Tarih Muhammadiyah, Logos Publishing House, Jakarta, 1995. Manan, Abdul, Hukum Islam Dalam Berbagai Wacana, Jakarta, Pustaka Bangsa, 2003.

Dalam "Peranan Peradilan Agama Hukum Perspektif Pembaharuan Putusan Islam: Studi Kasus terhadap Putusan-Putusan Dilingkungan Peradilan Agama DKI Jakarta", Ringkasan Disertasi, Program Pascasarjana USU, Medan, 2004.
M.Echols, John dan Hasan Shadily, Kamus Inggris-Indonesia, Gramedia, Jakarta, 1975.

Qardhawi, Yusuf, Min Ajli Shahwatin Raasyidah Tujaddidud-diin, Terjemahan Nabhani Idris, Figih Tajdid dan Shahwah Islamiah, Islamuna Pres, Jakarta, 1997.

Sjadzali, Munawir, "Peradilan Agama Dan Kompilasi Hukum Islam", dalam Moh.Mahfud MD, dkk., (Eds), Peradilan Agama Dan Kompilasi Hukum Islam Dalam Tata Hukum Indonesia, UII Press, Yogyakarta,

Syarifuddin, Amir, Pembaharuan Pemikiran Dalam Hukum Islam, Angkasa Raya, Padang, 1993.

Departemen Pendidikan dan Kebudayaan, Kamus Besar Bahasa Indonesia, Balai Pustaka, Jakarta, 1989.

Forum Keadilan, Nomor 26, Tanggal 24 Oktober 2004. SKH Republika 5 Oktober 2004. 


\section{Biodata Penulis}

Jimly Asshiddiqie, Prof. Dr. SH. Ketua Mahkamah Konstitusi, Dosen tidak tetap pada program Pascasarjana Fakultas Hukum Universitas Isiam indonesia Yogyakarta

Zairin Harahap, SH. M.Si. Dosen tetap Fakultas Hukum UII Yogyakarta, menyelesaikan S1 pada Fakultas Hukum Uil Yogyakarta dan S2 pada Program Pascasarjana Kebijakan Publik Fisipol UGM Yogyakarta.

Moh. Hasyim, SH. M.Hum. Dosen Tetatp Fakultas Hukum UIl Yogyakarta. Menyelesaikan S1 pada Fakultas Hukum UGM Yogyakarta. Menyelesaikan S2 di Pascasarjana UGM Yogyakarta.

Machsun Tabroni, SH.,M.Hum. Dosen Tetap Fakultas Hukum Ull Yogyakarta. Menyelesaiakan S1 pada Fakultas Hukum Ull Yogyakarta. Menyelesaikan S2 pada Program Pascasarjana Fakultas Hukum UII Yogyakarta.

Ridwan, SH.M.Hum. Dosen Tetap Fakultas Hukum Ull Yogyakarta. Menyelesaiakan S1 pada Fakultas Hukum UII Yogyakarta. Menyelesaikan S2 Program Pascasarjana pada Fakultas Hukum Universitas Padjadjaran Bandung.

Mila Karmila Adi, SH. M.Hum. Dosen Tetap Fakultas Hukum Ull Yogyakarta. Menyelesaikan S1pada Fakultas Hukum UII Yogyakarta. Menyelesaikan S2 pada Program Pascasarjana Universitas Padjadjaran Bandung.

HS. Brodjo Sudjono, Prof. Dr. SH. MS. Rektor dan Guru Besar Fakultas Hukum Universitas Surakarta (UNSA)

Kusnu Goesniadhie Slamet, Dr. SH. M.Hum. Dosen Fakuitas Hukum Universitas Wisnuwardhana Malang dan STIH Ma'arit Sidoarjo. Menyelesaiakan S1 pada Fakultas Hukum Universitas Tritunggal Ssurabaya. Menyelesaikan S2 pada Program Pascasarjana Universitas Surabaya (UBAYA). menyelesaikan S3 pada Program Pascasarjana Universitas 17 Agustus 1945 (UNTAG) Surabaya.

Rohidin, Drs. MAg. Dosen Tetap Fakultas Hukum UII Yogyakarta. Menyelesaikan S1 pada Fakultas Syariah IAIN Sunan Kalijaga Yogyakarta. Menyelesaikan S2 pada Program Pascasarjana IAIN Syarif Hidayatullah Jakarta

Nurijhad, SH. M.Hum. Dosen Tetap Fakultas Hukum UII Yogyakarta. Menyelesaikan S1 pada Fakultas Hukum UII Yogyakarta. Menyelesaikan S2 pada Program Pascasarjana Univerșitas Indonesia Jakarta. 